\title{
Sinemada Felsefeden "Yararlanma" Yolları Üzerine
}

\author{
Çağdaş Emrah Çağlıyan*
}

\section{Özet}

Sinema çalışmalarında incelediğimiz filmleri birtakım felsefi metinlerle ilişkiye sokarken büyük bir özen ve özveriyle hareket etmemiz gerekir. Çünkü bazı durumlarda görülebilmektedir ki, bu felsefi metinlerde ortaya konulmuş olan düşünceler, elimizdeki görsel malzemenin yaratılma sürecinde dikkate alınmış olsa da, asli içeriğ̈inden uzaklaştırılmıştır. Üstelik daha da sakıncalı olanı, kimi filmlerde bu metinlerle ilişkilendirilebilecek bir imgeler yığının kullanmanın amacı olguda apaçık görünen gerçekleri görünmez kılmak olabilir. Söz konusu filmler üzerine yapılan pek çok çalışmada ise, filmde felsefi bir düşüncenin çarpıtılma ve bozulmasına sessiz kalındiğına tanık olmuşuzdur. Burada ise, yalnızca yönetmenin çıkarı kollanmaz; yönetmenin kendince gösterdiği ipuçlarından yola çıkıp kendisine işaret edilmiş olan metinlerle ilişkiye sokan eleştirmen de kendi çıkarını düşünerek hareket eder. Her iki taraf da -örtük biçimde de olsa-derin bir düşünce dile getirdikleri iddiasındadır ama bu düşüncelerin olgunun gerçekliğiyle, yaşamın kendisiyle bağı kopmuştur.

Bu bağlamda, çalışmamızda, birtakım felsefimetinlerin yalnızca tek bir boyutuyla ele alındığını ve böylece eğilip büküldüğünü gözlemleyebileceğimiz bazı film örneklerini inceleyeceğiz. İnceleyeceğimiz örnekler, filmlerinin ardında hep derin bir anlamın aranmasının artık bir alışkanlığa dönüştüğ̈̈̈ Zeki Demirkubuz ve Reha Erdem'e ait olacaktır. Onların filmlerinde gözlemleyebileceğimiz, insanın kötücüllüğüne, usdışı ve iç̧üdüsel bir varlık oluşuna ilişkin vurguya, söz konusu filmlerin ilişkilendirildiği metinlerde ne şekilde yer verildiğini göz önünde bulundurmamız önemlidir. Çünkü insanı salt aşă̆ılık yönleriyle ele almak ve bunda bir derinlik bulmak, sonunda insanın uğradığı haksızlığın meşrulaştırılmasına zemin hazırlar. Kendimizde derinlik gördüğümüz böyle bir an, egemenlerin çıkarlarıla da örtüştüğümüz andir.

Bir düşüncenin yalnızca tek bir yanın vurgulamak, bu düşüncenin özsel yanından ziyade yalnızca işimize gelen yanın dikkate aldiğımıza ilişkin bir kuşku doğuracaktır. Bu kuşkuyu savuşturacak olan ise, gerek görsel malzemenin oluşturulmasinda gerekse bu malzemenin yorumlanmasinda tümüyle dürüst bir doğrultuda hareket etmek olacaktır. Bu dürüstlük, bizim çıkarımıza aykırı olabilir ama geçerliliği daha kesindir.

Anahtar Sözcükler: Türk Sineması, kötücüllük, usdışılık, çarpıtma, sinemada felsefe.

ORCID ID : https:/ / orcid.org/ 0000-0003-4013-4727

E-mail : cagdasc@baskent.edu.tr

DOI: $10.31122 /$ sinefilozofi. 737620

Geliş Tarihi - Recieved: 14.09.2020

Kabul Tarihi - Accepted: 12.12.2020 


\title{
A Discussion About The Ways Of “Utilization” From Philosophy In Cinema
}

\author{
Çağdaş Emrah Çağlıyan*
}

\begin{abstract}
We must behave with much attention and devotion while correlating the films we analyze with several philosophical thoughts. Because in some cases, we can see that, these philosophical thoughts are suspended from their essential content even they are considered within the process of creation of the visual content we work on. Also, it's more objectionable that, the aim behind using a pile of images those can be related to some philosophical texts, can be hiding factual matters obviously can be seen. We can witness that plenty of works being silent to the distorting and spoiling a philosophical notion in some films. In this case, it's not only the director's benefit protected, the critic also looks after its own self while correlating the referred texts with the film by following the clues the director showed. The both sides pretend to mention deep ideas, but the link between these ideas and obvious facts is broken.

In this context, we research some film samples which seem to be included several philosophical ideas superficially and deformative. The samples in our resarch will be belong to Zeki Demirkubuz and Reha Erdem, cause there is an addiction to search deep meanings in their films. It's important to consider that, the emphasis regard to evilness, irrationality and animality of human in some philosophical texts which are generally seen in relation with aforasaid films. Because approaching humans just in respect to their inferiority and finding deepness in that approach (thought), leads up to the legitimation of the injustice people meet with. Such a moment we find deepness in ourselves is the moment we coincide withe the benefits of the sovereigns.

Emphasizing an idea's only one aspect, makes us doubtful about considering that idea in a self-seeking way. We can parry that doubt by behaving totally honest while both creating a visual material or interpreting it. This honesty can be against to our profit, but its validness is more certain.
\end{abstract}

Key words: Turkish Cinema, evilness, irrationality, distortion, philosophy in cinema.

ORCID ID : https:/ / orcid.org/ 0000-0003-4013-4727

E-mail : cagdasc@baskent.edu.tr

DOI: 10.31122/sinefilozofi.737620

Geliş Tarihi - Recieved: 14.09.2020

Kabul Tarihi - Accepted: 12.12.2020 


\section{Giriş}

Bir konuya ilişkin yorum ya da yargılarımız, hangi yönüyle derin düşünce ürünü sayılabilir; onların bir değer taşıdığını iddia etmemiz ne şekilde olanaklı olabilir? Bu konuda önceliği, yorumumuzu yönlendiren eğilimin taşıdığı dürüstlüğe verebiliriz. Bu dürüstlük ne denli yoğunsa, düşüncemiz de o denli derinleşir. Eğilimimizin dürüstlüğü, bizi okuduğumuz metnin anlamını açığa kavuşturma yönünde güdüler ${ }^{1}$. Metin bizim için açık hale geldiğinde, o metnin oluşturulmasına neden olan derdi kavrarız. Bu dert, yazarın anlatımında somutlaşsa da, içinde çıktığı çağın içerdiği bir problemi ortaya koyma, buna bir çözüm arama çabasını dışavurur. Okuma eylemimizdeki dürüst tutumumuz sayesinde böyle bir derdin ayırdına varınca, kendimizi bu derdi gerek içinde bulunduğumuz çağ ile, gerekse bireysel yaşam deneyimimiz ile ilişkilendirmekten alıkoyamayız. Eskinin üstünden çok zaman geçmiştir, ama benzer sorunlar şekil değiştirerek sürmektedir. Üstelik, okumanın ardından yapacağımız bir içgözlem ile, genele yayılmış olan sorunun öznel alandaki karşılığını da açığa çıkarmaya çalışır, böylece özel ve genel, tikel ve tümel arasında bir koşutluk kurarız. Böyle bir koşutluğu temellendirebildiğimizde, okuduğumuz metnin her çağa direnen kalıcılığını görür, kendi okuma deneyimimizdeki edimselliği de sağlamış oluruz.

Peki, okuduğumuz bir metin bizim için ne zaman tam anlamıla anlaşılmaz olur? Bazı durumlarda, incelediğimiz metni kendi işimize yarayacak şekilde okumaya yöneliriz. Eğer bize alıntı yapma şansı veriyorsa, çalıştığımız başka bir konu için ek bir kaynak oluşturuyorsa ya da en azından kendisinden haberdar olmamız bir işimize yarayacaksa, o metin bize yarar sağlayacak gibi görünür. İşimize geldiği şekilde bu metni ameliyata alır, uzuvlarını kesip kullanır; sonunda yeniden işimize yarayacağı bir dahaki sefere kadar morga kaldırırız. Çıkarımıza hizmet ettirdiğimiz bu metinle çok yakın ilişki kurmuş görünürüz; ama aslında onu bütüncüllügüüyle kavrama yetisinden yoksunuzdur. Ne okuduğumuz metnin asıl derdini merak ederiz, ne de onu kendi yaşamımızla, ya da daha yerinde bir ifadeyle, yaşamımıza yönelik kavrayışımızla bir bağ kurarak değerlendiririz. İşe yarar bir parça aramaya koyulduğumuz metnin özü bize görünmez, dolayısıyla ölüdür ve kullanıldıktan sonra bizim için miadını doldurur. Dolayısıyla, yalnızca tikel çıkar için kullanılması nedeniyle, ancak tikeli aşamayacak eserlere kaynak oluştururlar. Bir bakıma, işimize yarasın diye katlettiğimiz metnin artık ölü durumdaki uzuvlarını alır ve gelişigüzel birleştirerek yeni bir ölü yaratırız. Aslında ortaya çıkan ucubenin ölü olduğunun farkındayızdır, ama onun yaşıyor olduğuna inanacak türdeşlerimiz olduğunu biliriz; ne de olsa ortalıkta ölüden bol bir şey yoktur ve bu bolluk da bizim çıkarımızı güvenceye alır.

Yukarıdaki açıklamalarımızdan hareketle, bu çalışmada, okuduğumuz metni çarpıtma eğilimimiz ve bu eğilimimizin bazı "yazarlar" (auteurler de diyebiliriz) tarafından yönlendirilmesi üzerinde durulacaktır. Sinema yapıtlarını doğrudan bir metin olarak değerlendirmesek de, sinema sanatında asıl yaratıcılık payesini verme alışkanlığında olduğumuz yönetmenleri auteur (yazar) olarak tanımlama eğilimindeyizdir. Bu yazarlardır ki, filmlerine "felsefi bir derinlik" katkısında bulunması için yararlandıkları metinleri yorumlama özgürlüğünü uç noktaya taşır ve bu metinleri bağlamından tümüyle uzaklaştırırlar. Bu bağlamda, inceleyeceğimiz örnekler ise, filmleri üzerine felsefi çıkarımlar yapmanın artık neredeyse bir geleneğe dönüştüğü yazar-yönetmenlerimizden iki tanesine, Zeki Demirkubuz ve Reha Erdem'e ait olacaktır². Bu yönetmenlerin bazı filmlerinde rastladığımız temaların ilişkilendirilme eğiliminde olunduğu felsefi konularla bağını tartışacak, kurulan bağın

\footnotetext{
1“Okuduğumuz metin” derken kastedilen, yazılı metinlerdir. Filmlerindeki yaratıcı rolüne vurgu yapılan yönetmenlerden yazar (auteur) olarak bahsetme alışkanlığı olsa da, bir filmin kendisinden bir metin olarak bahsetmek çok tartışmalı bir konudur. Çalışmamızda, yönetmenlerin filmlerinde birtakım metinlere kattıkları yorumun tartışmalı yanlarına dikkat çekecek olsak da, filmleri birer metin olarak değerlendirmemekteyiz.

${ }^{2}$ Konumuza ilişkin ülkemiz yönetmenlerinden örnekleri, kuşkusuz ki, arttırabiliriz; ancak bunun için bir makalenin alçakgönüllü sınırları yetmeyecektir. Bu yönetmenlerin özellikle seçilmesinde, birinin tümüyle yalın ve doğal, diğerininse abartılı ve tiyatral uçlarda yer alan bir biçem benimsemiş olmaları etkili olmuştur. Arada kalan bölge, ileride daha kapsamlı çalışmalarca doldurulmayı beklemektedir.
} 
ardındaki temelsizliği açığa çıkarmaya çalışacağız. Ancak amacımızın yalnızca bu temelsizliği göstermek olmadığını belirtmeliyiz. Çünkü temelsizliğin ortaya konulması, ancak bizi okuyup izlediklerimizle ilgili ayağı yere basmayan çıkarımlarda bulunmaktan alıkoymaya hizmet ederse işlevsel olabilmiş demektir.

\section{Felsefi Düşüncelerin "Kullanımı"na İlişkin Sinemamızdan Örnekler}

Bir metni okurken takındığımız çıkarcı tavır, tahmin edebileceğimiz üzere, çağımızdaki her türden yazar tarafından da az çok bilinmekte ve paylaşılmaktadır. Bu konuda önceliği kendi filmlerinin yazarlığını da üstlenen birtakım yönetmenlere vermek yersiz olmayacaktır. Ne de olsa sinema, bir imgeler bolluğunu doğrudan karşımıza getirmek ve daha kısa sürede ulaşılıp tüketilmek konusunda doğrudan üstünlüğe sahiptir. Üstelik, izlediğimiz film, sayg1 duyulan bir yönetmene aitse perdede gördüklerimizden bir anlam çıkarma yönünde daha kararlı bir tutuma sahip oluruz. İşte bu durum bizi daha kolay yönlendirilmeye açık kılar, hem de kendimizi bu konuda tam bir uzman gibi görmeye başlamışken. Yönetmenlerin bir kısmı da, bir ihtimal, anlam bütünlüğünü göz önünde bulundurmadan okudukları metinlerden kimi parçaları işlerine geldiği gibi kullanır, kimi imgeler aracılığıyla bu metinlere göndermelerini yapar ve bize de bu imgeleri, gönderimde bulundukları kaynakla bağlantılandırmak düşer. Sonrasında bu işin üstesinden gelebildiğimizde ise, buna bir yücelik atfetmekten geri durmayız. Peki, bu imgeler ve atıfta bulundukları düşünceler, filmin ortaya konulduğu bağlamı gözden kaçırmak ve bizi oyalamak için işlenmiş olamaz mı? Ek olarak, bu filmlerde, insana ait bir gerçeklik mi açığa vurulur, yoksa dönemin koşullarını gözetme çabası gereğince, insana ait gerçekliği çarpıtma işine mi soyunulur? Genellikle yazar-yönetmenlerimize toz kondurmak ve onlar üzerine yazdıklarımızı hiçleştirmek istemediğimiz için bu konudaki kuşkularımızı rafa kaldırmayı yeğleriz.

Şimdi bu konuyu daha açık kılmak adına somut örneklere başvurmamız yerinde olacaktır. Bu amaçla, sinemamızın son yirmi yılında yazar-yönetmen olarak hitap ettikleri kitlece sayg1 duyulan Zeki Demirkubuz ve Reha Erdem'in filmlerinden yararlanacağı. Öncelikle, insana ilişkin gerçekliği betimleme konusunda, her iki yönetmenin ortaklaştı ̆̆ bazı noktaların olduğunu söyleyebiliriz: İnsandaki usdış1lık, kötücüllük, acizliğin vurgulandığı "derin bir kavrayışın yansıtılması". Öyle ki, genellikle olay örgülerinde de her ne kadar kendi güçsüzlüğünü, içgüdüsel itkilerini yadsımaya kalkışsa da, insanın sonunda önüne konulan seçeneğe boyun eğmekten kurtulamadığını görürüz. Bu öyküleme biçimi öyle bir yolda yapılır ki, örnekleyecek olursak, umutsuzluğu Varoluşçuluk ile, acizce boyun eğmeyi de yazgi sevgisi ile ilişkilendirmeye yönlendiriliriz. Ki sinemayla ilgili çalışmalarda genellikle dikkate alındığı yönleriyle Varoluşçuluk, pek çok yönetmene de oldukça işlevsel bir çerçeve sunar.

$\mathrm{Bu}$ bağlamda dikkate alınan kısım, Sartre ve Camus gibi yazarların romanlarındaki kahramanların kayıtsızlığında vücut bulur ki, bu kayıtsızlığın yorumlanma biçimi de çoğunlukla boşvermişlikten ibarettir. Konuya ilişkin aklımıza gelebilecek örneklerden ilki, annesinin ölümünün hemen ardından bir yandan günlük yaşamını aynı kayıtsızlıkta sürdüren, öte yandan sevgilisi ve arkadaşıyla sahile giden Mersault olacaktır (Camus, 2013). Yine önemli bir etki kaynağı olarak, elinde yalnızca "şimdi ve burada olmaklık"tan başka bir şey olmadığını "apaçık" bir şekilde kavrayan, ancak bu kavrayışın verdiği "bulantı" hissi nedeniyle gittikçe edilginleşen Roquentin'i anabiliriz (Sartre, 2010). Roquentin, her türlü eylemin "gereksiz bir olayın ortaya çıkmasına neden olacağı"nı düşünmeye vardığı için eylemden geri durur; hatta onun için yaşam öyle bir boşluktan ibarettir ki kendi canına kıymak bile gereksiz olacaktır (Sartre, 2010: 168, 175). Benzer şekilde, birlikte olduğu kadın hamile kaldıktan sonra, onunla evlenme konusunda isteksiz davranan, hatta sevgilisinin kürtaj masrafını karşılamak için hirsızlık yapmaya yeltenen Mathieu'yü de aklımıza getirebiliriz (Sartre, 2011). Mathieu, kendi denetimi altında olan şeylere yalnızca "elini uzatır"; ama her şey olup bitene kadar "o şeyleri almak için yerinden kıpırdamaz" (Sartre, 2011: 115). Bir yandan istediği yere 
gidebilme, her türlü belirlenimden bağışık kalabilme olanağına sahiptir, öte yandan sahip olduğu bu özgürlüğü "demir parmaklıkları olmayan bir kafes" gibi hisseder (Sartre, 2011: 164). Yani özgürlük üzerine düşünüp akıl yürütürken, tümüyle eylemsizliğe gömülür; sorumluluktan kaçamayacağını kabul etmesi ise artık sorumluluğu üstlenmekten kurtulana kadar sürecektir. Bu eylem biçimine yol açanın ise, evrende varolan her şeyin ardındaki rastlantısallık ve nedensizliğin kavranışı olduğunu görürüz. Her şeyin "temelsiz ve nedensiz" olduğunu idrak etmek insanın yüreğini bulandırır ve insan şunu düşünmekten kurtulamaz: “Var olan her şey, nedensiz ortaya çıkar, zavallılı̆̆ı yüzünden varoluşunu sürdürür ve rasgele ölür" (Sartre, 2010: 179 - 182). Öyleyse bu kahramanları -daha doğrusu bu kahramanlar aracılığıyla Varoluşçuluk'u- yalnızca bu haliyle ele almanın bizi nereye vardıracağı da açıklık kazanacaktır: İnsan "temelsizlik"te temellenen böyle bir noktadan yüzeysel bir şekilde yola çıktığında, kendisi dahil herkesteki boşluğu apaçık biçimde kavrar, bu kavrayışın, kendisini başkaları nezdinde üstün kılacağını düşünür; bu öyle bir üstünlüktür ki, "yoğun tefekkür" den kaynaklanıyor görünen her türlü eylemsizliğe de bir soyluluk görünümü kazandırır.

Ancak gerek bu yazarların gerekse ve daha önemli olarak onların öncellerinin temel yapıtlarında Varoluşçuluk ile ilişkilendirilebilecek özsel yan gözden kaçırılır: Sonlu-ölümlü bir varlık olmaktan dehşet duymak, bu dehşeti dindirebilmek için eyleme geçmek ve kendini kalıcı kılacak biçimde ortaya koymaya çabalamak. Bu yanını dikkate aldığımızda, insanı doğrudan ortaya koyduğu şeyden, yani eyleminden yola çıkarak tanımlamak ve onun eyleminin ardındaki özgürlüğün zorunlu hattını soruşturmak yaşamsal olacaktır. Varoluşçu düşüncenin bu izleğini dikkate aldığımızda, aklımıza ilkin Sartre' ın Varlık ve Hiçlik'te yazdıkları gelecektir: "İnsanın özgürlügü insanın özünden önce gelir ve onu mümkün k1lar, insan varlığının özü, onun özgürlüğ üi içinde askıdadır (...)" (2009: 75). Bu bağlamda, insan varolduğu andan itibaren özgürdür; “(...) özgür olmaya mahkûm olduğundan dünyanın tüm ağırlığını omuzlarında taşır; insan dünyadan ve varolma tarzı olarak kendi kendisinden sorumludur" (Sartre, 2009: 687). Dolayısıyla, yukarıda andığımız roman karakterlerinden yola çıkarak vardığımız -ya da varmayı tercih ettiğimiz- yerden farklı bir yere gelmişizdir. İçinde bulunduğumuz dünyanın ve olaylar zincirinin temelsizliği, bize kaçış şansı bırakmaz, edilginliğimizi haklı çıkarmaz; tersine bu hiçlik evreninde kendimizi eylemli biçimde ortaya koyma sorumluluğuyla karşı karşıya bırakır; artık elimizde kendimizi aklamaya yarayan hiçbir "mazeret" kalmamıştır. Sartre'dan alıntılarsak: "Başıma gelen her şey benim aracılığımla gelir ve ben ne bunlara üzülebilirim, ne isyan edebilirim, ne de bunları sineye çekebilirim. Zaten, başıma gelen her şey benimkidir; bundan anlamamız gereken, en başta, insan olarak benim her zaman başıma gelen her şeyin üstesinden gelebilecek olmamdır" (2009: 688).

Soruşturmamızı derinleştirmek adına, burada aktardığımız haliyle Varoluş̧̧u düşünceyi, sonlu bir varlık olarak insanın özgürlüğünün zorunlu şekilde varlığa gelmesine dikkat çekme ve insanı karşılaştığı, kendisini içinde bulduğu zorunlulukla uzlaştırma eğilimiyle önceleyen bazı önemli filozofları anmamız yararlı olacaktır. Çok geriye gitmeden, çalışmamızda Schelling ve Hegel'in bu bağlamdaki, genellikle gözden kaçırılan, düşüncelerinden kısaca bahsedebiliriz.

Öncelikle Schelling'in düşüncesine baktığımızda, onun dizgesinde tanrısal gücün erişemediği karanlık bir "zemin"in varlığına dikkat çekildiğini görürüz. Zemin, bir bakıma her şeyi önceleyen "kaos" gibi, başlangıçta yer alır, ancak bu karanlıktan usun 1şımaya başlamasıyla birlikte daha yüksek bir ilkeye, Tin'e ulaşıldığını görürüz ki; Tin'in ereği de kendi bilincine ve özgürlüğe erişmektir. İnsan özgürlüğüyle ilgili konuşmaya kalktığımızda da, bir yanda bu karanlık zemini, öte yanda ise tanrısal ilkeyi hesaba katmamız gerekir. Bu iki karşıt gücün etkileşimi, insanı iyi ya da kötü bir eylemde bulunma konusunda özgür bırakır: "İnsanda karanlık ilkenin tüm kudreti ve aynı zamanda 1şığın tüm gücü mevcuttur. Onda en derin uçurum ve en yüksek gökyüzü ya da her iki merkez birden vardır" (Schelling, 2017: 58).

Peki zemindeki kötülüğge ya da tanrısal 1şıktaki iyiliğe neden olan etken nedir? İnsan, 
karanlığın etkisine girdiğinde görüşü kendi bireyselliğinin ötesine uzanmayacak, evreni kavrayışında kendini merkeze alması onu kötücül eylemlere eğilimli hale getirecektir. Usun tanrısal ışığı ise, olayları tüm genelliğiyle kavramaya yönelir ve kişiyi bu genel olan içindeki konumunu göz önünde bulundurarak davranmaya iter. Schelling'den aktaracak olursak: “Tanrı'nın iradesi her şeyi evrenselleştirmek, her şeyi yükselterek 1şıkla birleştirmek ya da bu birlikte tutmaktır; diğer yandan zeminin iradesi her şeyi tikelleştirmek, yaratılana özgü hale getirmek ister" (Schelling, 2017: 75). Dolayısıyla, zeminden kaynaklanan bir eylemde bulunmak insan varlığına özgü olmakla birlikte insanın kavrayışındaki eksiklikten kaynaklanır. Gördüklerini evrensel yanıla kavrama yoluna girdiğinde ise insan tanrısal bir eylemi gerçekleştirir, ki bu bağlamda tanrısal olan insansal olandan ayırt edilemez -hatta ancak bu haliyle insansal olanda vücuda gelir-. Dolayısıyla, insanda, zeminden gelen karanlığın bulunması, onu salt karanlığa mahkûm olmaya -ya da mahkummuş gibi görmeyeitemez; o aynı şekilde ışığa erişebilme yetisine sahip bir varlıktır ve ona kalıcılığını veren de ancak bu tanrısal yanıdır. Bu bağlamda, dikkat etmemiz gerekir ki, Sartre, özgürlüğg̈ sorumluluk, başkalarına karşı sorumluluğumuz ile bağdaştırırken, benzer şekilde, genel olanın kavranmasını salık verir; onun tanritanımaz olması ya da genel olanı tanrısal olanla bir tutmaması, bu genelliğin mahiyetini değiştirmeyecektir.

Schelling'de rastladığımız, tanrısal ve insansal olanın, sonsuz ve sonlunun birliğini Hegel'in dizgesinde de görebiliriz. Bu noktada aklımızdan çıkarmamamız gerekir ki, burada sonlu olan sonsuz olanın içinde erimez; aslolan sonlu olandır ve sonsuz da ancak sonlu olanda görünür olur. Hegel'in düşüncesinde, Tin'in yalnızca bir Töz değil aynı zamanda bir Özne de olduğuna dikkat çekilir (Hegel, 2004); tinin özne oluşu ise onun sonlu bir varlıkta cisimleşmesini gerektirir. Çünkü sonlu bir varlık, bir sınırla çevrelenmiştir ve ancak bu sınır aracılığıyla eyleme geçecektir; sınır kendi ötesini işaret ederken cisimleştiği varlığa da eyleminin yönünü ve ereğini verir. Sonlu varlıkların asıl hakikati, onların sonlu oluşudur ve onların "sonlu şeyler olarak varolması", aynı zamanda ölümü, kendi yokedici ilkelerini en katı haliyle kendi içlerinde taşımasını gerektirir; "onların doğum saati, ölüm saatidir" (Hegel, 1969: 129). Sonlu olan, her zaman kendi sınırına doğru ilerlerken, sonsuz olanı bulacağımız yer neresidir? Sonlu olanın dışında, tümüyle aşkın bir sonsuz varlıktan söz edilebilir mi? Hegel'in düşüncesi uyarınca, buna olumsuz yanıt vermek gerekir; sonsuz, ancak sonlu olanın sürekli kendini aşma ediminde devam eder, sonlunun kendini aşması ise onun sonsuzluğa ulaşmasına değil, kendi sınırının ötesinde başka bir sonlu tarafından eyleminin sürdürülmesine işaret eder: “(...) sonluluk yalnızca kendini aşmadır; böylece Sonsuzluğu, kendi başkasını içerir. Benzer şekilde, sonsuzluk, yalnızca sonlunun bir aşılması olarak vardır; böylece özsel olarak kendi ötekisini içerir ve dolayısıyla kendisinde kendi başkasıdır" (Hegel, 1969: 145-146). Öyleyse, sonlu ve belirli varlığın (dasein) içerdiği sınırlama, onun eyleminin ilkesini de verir. Bu ilke gerçekliğe kavuştuğunda sonlu varlık da işlevini yerine getirerek sahneden çekilir ve yerini ardılına bırakır. İşte bu ilerleme içeren döngüsellikteki süreklilik³, bu "kendisini kapayan hareket", sonsuzu nerede bulacağımızı da gösterir. Bir bakıma, bizim kendi eylemimiz aracılığıyla kendi sınırımıza ulaşmamız, sonsuzlukla bağımızı kurar ve bizi tüm bu tümellikte bir parça kılar. Biz kendi sınırımıza ulaşmaktan, bu sınırla tanımlanmaktan geri duramayız ve kendi varlığımızın daha genel bir gerçeklikle bağını yadsıyamayız.

Bu bağlamda, aktardığımız düşüncelerin Varoluşçuluk ile nasıl ilişkilendirilebileceği de açılık kazanacaktır. Yukarıda anmış olduğumuz düşüncelerden hareketle, bireysel varlığın

\footnotetext{
${ }^{3}$ Aslında bu konuda Tarihte Akıl' da yer alan şu sözler daha açıklayıcı olacaktır: "Bitki tohumla başlar; ama tohumu aynı zamanda bitkinin tüm yaşamının sonucudur: bitki tohumu meydana getirmek için büyür. Fakat tohumun bireyin başlangıcı ve aynı zamanda sonu olması, çıkış noktası ve sonuç olarak ayrı, yine de aynı olması, bir bireyin ürününün bir başkasını meydana getirmesi yaşamın güçsüzlüğünü gösterir" (Hegel, 2014: 65). Dolayısıyla sonlu olanı bir bitkideki tohum gibi de düşünebiliriz; tohum bir yandan sona ererken öte yandan ondaki yaşam ardılında devam eder. Sonlu insan yaşamına geldiğimizde bu sürekliliğin ussal ilerleme ile bir arada olduğunu görürüz. Sonlu olanın devimindeki süreklilik sonsuz olana işaret ederken, bu süreklilikteki ilkenin kavranışı sonlu us aracılığıyla olur ki, Tin'in kendisi de bu ustan ayrı bir şey değildir.
} 
sonluluğunun kabul edildiğini, bilinçli insan varlığının -dizgede Tanrı ya da Tin'e merkezi bir konum verilmiş göründüğünde dahi- evrenin kavranmasındaki ve değer yaratmadaki temel güç haline geldiğini görebiliriz. Bilinç ve özgürlük iç içe gider ve özgürlük salt amaçsızca savrulma ile bir tutulmaz. Örneğin, Schelling'in düşüncelerini hatırladığımızda, onun özgürlüğü "kendi özünün yasalarına bağlı olarak eylemde bulunma" ile özdeşleştirdiğini görebilir; onun şu sözlerinde ise Sartre için önemli bir esin kaynă̆ı bulabiliriz: “(...) içsel zorunluluk bizzat özgürlüktür; insanın özü bizzat insanın kendi eylemidir; zorunluluk ve özgürlük, tek bir öz olarak birbirinin içindedir, yalnızca farklı açılardan bakıldığında farklı görünürler (...)" (Schelling, 2017: 79) ${ }^{4}$. Schelling'e göre, insan eylemiyle özü arasında bir ayrım varsayamayı; tıpkı Hegel'in düşüncesinde de varsayamayacağımız gibi. Eğer biz varolanlardan hareketle temeldeki ilkeyi belirleyebiliyorsak, insanın özünü de onun ortaya koyduğu eylemden hareketle belirleyebiliriz. Burada "öz"ün temel ilke olmasi ${ }^{5}$ aradaki benzeşimi, yani öz ve eylem birliğini gözden kaçırmamıza neden olmamalıdır. Schelling'in şu sözleri, öz ve eylem (hatta belki de varoluş) birlikteliğini ortaya koyması bakımından aydınlatıcı olacaktır: "Yaratılışta her şey bir uyum içindedir ve bizim tasavvur ettiğimiz gibi bir ayrışma ya da ardışıklık yoktur, daha önce olanın içinde sonra olacak olan çoktan etkindir, her şey tek bir sihirli vuruşla aynı anda gerçekleşir" (2017: 81 - 82).

Öyleyse söyleyebiliriz ki, filmlerdeki izdüşümünü kayıtsızlık, eylemsizlik, rastlantı uyarınca savrulma gibi durumlarda gördügüümüz düşünce, Varoluşçuluğun düşünsel bir birikimin ürünü olan özsel yanı değil, ancak soluk bir yüzeyidir. Varoluşçuluğun öz ve eylem birliğini, insanın ortaya koyduğu şeyle özdeşliğini savlayan yanı ise, ne okuduğumuz metinleri kendi yararına olacak şekilde yontanlarımızın ne de film çekmek için fonlarına muhtaç olunan, çağın gerçek egemenlerinin çıkarlarıyla örtüşür. Eylemsizlikte derinlik bulmak, kendi eylemsizliğimizi haklı çıkarmaya yarar ve durduğumuz yerden verdiğimiz tepki(sizlik)lerin etkisinin yanılsamadan ibaret oluşunu gözardı etmemize gerekçe oluşturur.

Bu bağlamda, ilk örneğimiz olarak Zeki Demirkubuz'un Bulantı filmiyle başlayabiliriz. Anımsayacağımız üzere, filmde başkarakter olan akademisyen Ahmet, eşini ve çocuğunu bir kazada yitirir. Ancak bu durumu hiç umursamaz görünür, sevgilisiyle ilişkisine ve günlük rutin eylemlerine aynı kayıtsızlıkla devam eder. Ancak bu nasıl bir kayıtsızlıktır? Demirkubuz'un ve aslında benzer yönelimdeki pek çok yönetmenimizin ele aldığ 1 biçimiyle bu kayıtsızlık durumu, insanın en yakın olduğu kişilerle dahi arasındaki aşılmaz engelleri gözümüze sokmakla yetinir. Bunu kabul etme yürekliliği de yalnızca mutlak kayıtsızlığa sahip kişiye ait gösterilir. Bunu idrak etmiş kişiye düşen ise, başkalarıyla paylaştığı aşağılıkça özellikleri kabullenip, ilişkilerini buna uygun biçimde yaşamak olacaktır. Dolayısıyla, eğer özgür olmak istiyorsa hiçbir bağlanım içine girmemeli, çevresindekilere de elden geldiğince aldırış etmemelidir.

Mademki herkes, olanca içgüdüsel ve çıkarcı tepkilerle ilişki kurmaktadır, kayıtsız kişi de bu durumu kendi hazzını sürdürmeye yarayacak şekilde kullanmalıdır. Ahmet, kendi yaşadıklarından ve ilişkide olduğu kişilerden hareketle insana karşı içten içe bir tiksinti duyar ve filmde de doğrudan işittiğimiz üzere duyduğu bulantı, sabah uyanmasını engellemeye başlar. Bulantıyı dengelemek adına evine gelen gündelikçi kadının oğluna iyi davranır ve en sonunda bu duygu onun için dayanılmaz bir hale geldiğinde kadının evine gidip ayağına

\footnotetext{
${ }^{4}$ Bu bağlamda Hegel'in; “Yalnızca yasaya boyun eğen istenç özgürdür: Önünde boyun eğdiği şey kendisi olduğu, kendisinde kaldığ1 ve böylece özgür olduğu için" (2014: 122) sözlerinde, insanın kendi koyduğu yasanın tümel bir yasada, devletin anayasasında cisimleştiğine işaret edilir ve buna göre insan anayasaya uyarak, ussal olanı kendi özüyle bir tutup yasa olarak tanıarak özgürlüğe erişir. Dolayısıyla burada söz konusu olan şey her zaman için, özü uyarınca uyduğu zorunlu yasa tarafından belirlenmenin özgürlükle bir tutulduğudur. Burada dayanak, anayasanın somut belirlenimidir ama ifade ettiği şey ise bir bakıma insanın bilinçli seçimidir. Hegel'de siyaset felsefesiyle ilişkilendirildiğini söyleyebileceğimiz bu "seçim" kavramına, Sartre'ın Varoluşçu düşüncesinde daha basitleştirilmiş ve bireyselleştirilmiş bir şekilde yer verildiğini görürüz.

${ }^{5}$ Sartre'
} 
kapanıverir. Burada yönetmenin eşelememizi istediği gönderim noktaları açıktır: ilkin Yabancı romanının başkarakteri Mersault' nun annesinin ölümüne olan kayıtsızlığı, Sartre'a doğrudan referansla alınan bulantı hissi, kibirli bir adamın kendisinden daha aşağıda gördüğü, zor durumdaki bir kişinin ayağına kapanarak ağlamasındaki Dostoyevskivari arınma.

Oldukça açık bir şekilde bu işaret edilen gönderim noktalarını bulduğumuzda, bir kâşif heyecanıyla, hemen -örtük de olsa-bizden isteneni yapmaya, filmi söz konusu düşünce akımları ve yapıtlarla ilişkilendirmeye girişiriz. Ancak, genellikle ilişki kurduğumuz kaynaklardaki özsel yanı gözardı ederiz. Örneğin, şunu düşünelim; Mersault'nun kayıtsızlığının bize gösterdiği yalnızca insanın içindeki boşluk mudur? Benzer bir kayıtsızlığa, yalnızca Bulantı filminde değil, yine Demirkubuz'a ait -bu kez doğrudan Yabancı romanının serbest uyarlamasıolan Yazgı (2001)' da da rastlarız. Yazgı'daki başkarakter Musa, annesinin ölümünün ardından olanca kayıtsızlığıyla günlük işlerine devam eder, yüzeysel biçimde tanıdığı bir kadınla evlenir, cinayetle suçlanıp hüküm giyer. Ancak film, çok önemli bazı noktalarda romandan ayrılır: Musa'nın patronu, onun karısıyla ilişki içindedir, kendi ailesini katledip suçun Musa' nın üzerine yıkılmasına neden olmuştur; ancak ardından patron vicdan azabı nedeniyle intihar etmiş, Musa aklanmış, sonunda da kendisini aldatmış olan kadının bacağını okşayarak içindeki boşluğu ifade etmiştir. Doğrusu, filmde Meursault'nun "fiziksel ihtiyaçlarının çoğu zaman duygularını etkilediği" (Camus, 2013: 63) yönündeki düşüncesinin bir yansımasına Musa' da rastlarız; ancak Meursault' nun durumu salt kayıtsızlıktan mı ibarettir ve en sonunda asıl idrak ettiği şey kendi boşluğu mudur?

Öncelikle, Yabanci'da görürüz ki, Mersault'nun kayıtsızlığı, annenin huzurevinde olmasını normal karşılayan ama anne ölümü karşısındaki aldırışsızlığı kınayan toplumun ikiyüzlü eğilimini açığa vurmaya aracılık eder. Mersault, bu uğurda idam edilir belki ama, onun durumu insanın genele yayılmış bir ikiyüzlülüğü sürdürmektense, kendi doğasını dışavurma ve bu uğurda ölümü dahi göze alma potansiyeli taşıdığını gösterir. Romanın sonunda ise, başkarakter, toplumun genelinde süren ikiyüzlülüğ̈̈ “ölü gibi yaşamak"la bir tutar, yanıbaşındaki ölümün kesin varlığını yaşamının zorunlu varış noktası olarak görür ve özgürlüğünün bu yazgısal zorunlulukla birliğini kavrar. Dolayısıyla romandaki karakter, perdedeki benzerinin yaptığı gibi, insanı içsel olarak saltık bir boşluğa ve hayvansal bir varlık konumuna indirgememize izin vermez; onun durumunda, insan, özgürlüğün ardındaki yazgısallığı daha açık biçimde idrak eder -üstelik içinde yer aldığı yapıtın adı Yazgı değilken-.

Peki bu filmler üzerinde, en az Camus kadar etkide bulunduğu savlanan Dostoyevski'ye geldiğimizde, onun kimi karakterlerinde gözlemlediğimiz içgüdüsel ve usdışı özellikler, ona gönderimde bulunan pek çok filmde olduğu gibi, insan varlığının asli özellikleri olarak mı ele alınır? Dostoyevski'ye ilişkin olarak, göz önünde bulundurmamız gerekir ki, onun romanlarında yalnızca insanın usdışı bir varlıktan ibaret olduğunu, saygıyla kutsanan eylemlerinin ardında dahi aşağılık bir isteğin bulunduğunu görmeyiz. Aynı zamanda -hatta belki de daha vurgulu şekilde- en fazla aşağılamaya maruz kalandaki yüce yanı da görürüz. Dolayısıyla, Dostoyevski romanlarında yaşamda karşılaştığımız bu çelişkili ve usdışı yanın insanı hiçleştirmek için kullanıldığını söylemek güçtür, çünkü umut hep varlığını korur. Bu kısmı görmezden gelmek Dostoyevski' yi de bir bakıma hiçe indirgemek olur.

Bu noktada bir örneğe yer verebiliriz; demin Bulantı filmi bağlaminda andığımız "zor durumdaki kadının ayaklarına kapanarak arınma" eyleminin benzerini düşündüğümüzde ilk aklımıza gelebilecek olan sahnelerden birisi Suç ve Ceza (Dostoyevski, 2007) romanında yer alır: Raskolnikov eyleminin ağırlığına dayanamaz ve ailesine yardım edebilmek için bedenini pazarlayan Sonya'ya suçunu itiraf eder. Onu kendine yakın bulmasının ardında, aşağılık bir eylemin ardındaki yüce duyguların varlığını görebiliriz; ki Sonya' ya söylenmiş şu sözler bu konudaki savımızı destekler: "(...) böylesine bir yüz karası, böylesine bir bayağılık nasıl oluyor da tam tersi olan kutsal duygularla bir arada bulunabiliyor senin içinde?" (Dostoyevski, 2007: 
379). Kaldı ki, Karamazov Kardeşler (Dostoyevski, 2003) romanını anımsadığımızda, kutsal bir varlıktan ayırt edemeyeceğimiz Alyoşa'nın bir yanda dünyevi hazlara gömülmüş, kösnül Fyodor' un oğlu; öte yanda inançsız Ivan ve bedensel hazzına düşkün Dimitri' nin kardeşi olması bize yine karşıt uçta görülen duyguların iç içeliğini gösterir. Dolayısıyla insan salt kösnüllükten, bencillikten ibaret görülemez; o aynı zamanda en yüce eylemleri gerçekleştirebilme olanağını taşır ve en kötü koşullarda bu olanağın varlığı bizi insana ilişkin yaklaşımımızda umutlu kılar.

Dostoyevski'nin başka bir romanındaki, yine bir hayat kadını ile yapılmış bir konuşma ile devam edelim. Yeraltından Notlar (Dostoyevski, 2010)'daki başkarakterin genelevde ilişkiye girdiği kadınla konuşmasını anımsarsak, orada yeraltı adamının hayat kadınına sarfettiği sözlerin aslında çağımız insanının yazgısını dile getirdiğini görürüz. Yeraltı adamı ilkin, bu kadının tutsaklığını yüzüne vurur; patronları dost tutmasına izin verse dahi, bunun amacının onları tevekkül içinde boyun eğmeye teşvik etme olduğunu söyler, sonunda ise önündeki yazgıyı tüm kesinliğiyle gözler önüne serer: Ölümün kıyısındayken, ondan çıkar sağlayamayacak olanlar ona arkasını dönecek; öldükten sonra ise bir mezara tıkıp sonra içmeye gideceklerdir (Dostoyevski, 2010). Yani, insan varlığı, yanılsamadan ibaret olan kısa süreli rahatlama anlarıyla her gün çektiği eziyete katlanır; ancak işkenceli yaşamının sonunda ölüm kapıya dayanır ve en yakınlarından dahi merhamet göremez. Pek çok acıya katlanmış olan bedeni toprağa verildiği anda başlayan çürüme, yakınlarının belleklerine de bulaşır ve sonunda ona ait en küçük bir iz bile bırakmaz.

Pekibu romanın perdedeki serbest uyarlamasında sözünü ettiğimiz konuşmayıne şekilde görürüz? Yeraltı (Demirkubuz, 2012) filminin başkarakteri, hayat kadınına ilkin, defnedilirken mezarı suyla dolan bir kadından bahseder; ardından konuşma "her canlının bir gün ölümü tadacağı", can çekişirken en azından acıyı dindirmenin bir yolunu bulma çabasına girmenin kaçınılmazlığı gibi konular üzerinde sürer ve sonunda şu çıkarıma ulaşılır: insan acılar içinde ölecekse, onun için en iyisi bir an önce ölmek olacaktır. Görüleceği üzere, burada romandaki konuşmanın daha yüzeysel bir yorumunu görürüz; şimdiki varış noktası "insan mademki ölecektir, bunu en acısız biçimde yapmalıdır" düşüncesine dönüşmüştür ki, konuşmanın ardından başkarakterin hayvansı duygularla hırlayarak hayat kadınının üstüne yürümesi bu acıyı dindirmek için önerilen reçeteyi açık eder. Ancak romandaki konuşmadan yola çıtığımızda ise, insan sonlu yanını ve acı yazgısını tüm dehşetiyle yanıbaşında hissettiğinde dahi yaşamını aynı kararlılıkla sürdürmekten geri durmaz. Dolayısıyla, romanda insan salt aşağılık bir varlıktan ibaret görülmez; o öncelikle trajik bir varoluşa sahip olmasıyla öne çıkar.

Buna ek olarak, filmin başkarakterinin pek çok eylemi aracılığıyla insanın usdışı bir varlığa indirgendiğini -ve aslında Dostoyevski'nin de bu indirgeme işlemine alet edildiğinisöyleyebiliriz. Ancak Dostoyevski romanlarında karşımıza çıkan usdışı eylemlerin ardında hep ussal bir çıkarım olduğunu görmemiz gerekir. Raskolnikov'un cinayetinin ardında "bir bit" değil "bir insan" olduğunu ortaya koyabilme çabası vardır (Dostoyevski, 2007: 493); yeraltı adamı ise insanı usdışı eyleme itenin, "bir vida değil de insan olduğunu her an kendine kanitlamak" olduğunu belirtir (Dostoyevski, 2010: 46). Dolayısiyla Dostoyevski romanlarında gördüğümüz usdışı eylemlerin nedeni, insanın salt hayvansal bir varlıktan ibaret olması değil, tam tersine bu hayvansallığı yadsıyabilmek için kendi çıkarlarına aykırı eyleme girebilme istencidir. İște romandaki bu yanın gözardı edilerek insanın salt hayvansal varlığına indirgenmesinin önüne geçmek gerekir. Çünkü unutulmamalıdır ki, insana yönelik bir alçaltma girişimi, örneğin olgusallıkta devam eden haksızlığ eleştirmeye uygun bir zemin hazırlamaz, tam tersine, eninde sonunda haksızlığa uğrayan herkesin başına geleni hakettiğini düşündürmeye varır.

Yapıtlarındaki düşüncelerin pek çok kez çarpıtmaya maruz bırakıldığı başka bir örneğe geçebilirve yukarıdakine benzer yorumları, yine sinemayla uğraşanlarımızın vazgeçemediği bir kaynak olan Nietzsche' ye ilişkin olarak da yapabiliriz. Nietzsche' nin yapıtlarını bütünlüğüyle 
göz önünde bulundurduğumuzda, onun amacının insanı salt kötücül bir varlığa indirgemek, ancak kendini üstinsan konumuna yerleştirmek -böylece günümüz okurlarının kendilerini özdeşleştirebilecekleri bir tipleme yaratmak- olmadığını söyleyebiliriz. Ayrıca ekleyebiliriz ki, onu güdüleyen temel etken, çağın ikiyüzlü eğilimine duyduğu tiksinti iken, asıl derdi ise bu duruma karşı bir çıkış yolu aramaktır. Bu ise her yönüyle çok güç gerektiren bir iştir.

Pek çoğumuz, Nietzsche' nin yazdıklarının etkisine kapılıp "pazar yerindeki sinekler" den yakınıp küçük ve aşağılık kişilerin mağrur insanların yıkımına neden olmasının sıkıntısını duyarken (Nietzsche, 2000: 69 - 70) kendini güçlülerin yerine koyma eğilimine girer. Ancak gözardı ettiğimiz bir nokta vardır ki; Nietzsche' nin salt bu yazdıklarından yola çıkarak, güçlü kişilerin içine düştüğü çaresizlikten yakındığını söylemek yersiz olur. Kendi güçsüzlüğüne ve çaresiz hissederek içine düştüğü eylemsizliğe bir soyluluk atfetmek ve bunun avuntusunu okuduklarından çıkarmak isteyen bizizdir. Halbuki, Nietzsche'nin düşüncelerinin genelini gözden kaçırmazsak, bizim aşağı gördüğümüz kişi, eğer bir savaşımda bize üstün geldiyse, bizim çaresiz hissetmemize neden olduysa, zaten bizden güçlü demektir; üstün geldiği için avuntu arama ve eylemsizliğini haklı çıkarma gereksinimi de duymaz. Üstelik, biz pazar yerindeki sinekleri aşağılarken, çoğu zaman kendi içinde bulunduğumuz yerin de bir tür pazar yeri olduğunu gözardı ederiz. Çoğu kez kendi yargı ve görüşlerimizi kendi pazarımızdakilerle benzeştirir; aslında bize ait olmayan düşünceleri dile getirdiğimiz ürünlerle pazarda bir yer edinmeye çalışırız. Ancak pek çoğumuz, içinde bulunduğumuz ikiyüzlülüğü normal bir durummuş gibi sürdürür, günlük rahatımız uğruna buna son vermeyi aklımızdan bile geçirmeyiz. Ne de olsa benzeşlerimiz de, bizim gibi, kendini mağrur görür ve söz ettiğimiz yapıtları içselleştirdiğini düşünür.

Bununla birlikte, demin de söylediğimiz gibi, ülkemiz sinemasının yakın dönemdeki pek çok örneğinde dikkat çekici olan durum, insanın kötücüllüğünün, hayvansı yanının vurgulanmasıdır; hatta bu vurgu öylesine pekiştirilir ki insanı salt bu özelliklerden ibaret saymaya varır. Örneğin Zeki Demirkubuz' un pek çok filminde kötücüllüğün -ve yine hayvana özgü bir usdış1lığın-vurgulandığını görürken, Reha Erdem'in pek çok filmindeki asıl vurgunun hayvansı yanın yüceltilişi olduğunu görürüz. Onların filmlerinde gördügüüüz, insanın kötücüllüğü ve hayvansılığına -ya da içgüdüselliğine- ilişkin düşüncelerin ilişkilendirildiği düşünürün ise genellikle Nietzsche olduğunu söyleyebiliriz.

Ancak yukarıda da belirttiğimiz gibi; aslında Nietzsche'nin temel amacı, insanı salt kötücül ve hayvansı yanından ibaret göstermek değildir. Nietzsche'ye göre, insanın bir yandan aslında tümüyle içgüdüsel olduğu, bilincinin gelişmesinin ardında dahi içgüdülerinin bulunduğu doğrudur (Nietzsche, 1998) belki ama insan bundan dolayı tümüyle değersiz görünmez. Nietzsche'den aktarırsak: “İnsanda yaratık ve yaratıcı birleşmiştir: insanda malzeme, parça, fazlalık, çamur, dışkı, anlamsızlık, kaos vardır; ama insanda yaratıcı, heykeltraş, çekiç-sertliğii, izleyici-tanrısallığ1 ve yedinci gün de vardır" (2016: 153). Onun düşüncesinde insandaki içgüdüselliğe yapılan vurgu ise, insan varoluşundaki -ve genel olarak varoluştaki- yazgısal yanı görünür kılmaya yarar. İşte Nietzsche' nin varoluşun yazgısallığına yönelik ilgisi, onun kendine mahlas olarak seçtiği figüre de anlamını verir. Şimdi bu figüre ilişkin soruşturmamıza başlayabiliriz.

Pek çok filmde ve bu filmler üzerine yapılan araştırmalarda karşılaştığımız üzere, Nietzsche' nin bahsettiği şekliyle Dionysos figürü, doğaya övgü dizmek adına insanı alçaltmak amacıyla kullanılır. Bu durumla, özellikle Reha Erdem'in bazı filmlerinde karşılaşabiliriz. Öyle ki son filmi Koca Dünya' da doğrudan keçi imgesini kullanır ki, hemen kâşif güdülerimiz devreye girsin ve Dionysos bağlantısını kolayca kurabilelim. Filmde, yetimhanedeyken kardeş bildiği, henüz reşit olmamış Zuhal'in, verildiği koruyucu ailede kuma haline getirilmesini kabullenemeyen Ali, kardeşini kurtarmak için bu ailenin babasını öldürür ve sonunda kardeşlerin doğaya kaçmaktan başka çaresi kalmaz. Olay örgüsünün bize anımsatacağı örnek, 
hiç kuşkusuz, Badlands (Terrence Malick, 1973) filmi olacaktır. Badlands'in başkarakteri Kit de, Ali gibi güç koşullar altında çalışır ve henüz reşit olmayan kız arkadaşı Holly ile birlikte olmasına izin verilmez. Sonunda Holly' nin babasını öldürür ve birlikte doğaya kaçarlar ${ }^{6}$.

Koca Dünya filmine dönersek, doğadaki varolma savaşımı sırasında, -düşsel olup olmadığı belirsiz- bir keçi ile karşılaşırız ki, doğada yolunu kaybetmiş olanlar ona baba diye seslenir. İlkin Alzheimer hastası yaşlı bir kadın bu babanın peşine düşmüşken, ardından Zuhal onu baba saymaya başlar. Yaşlı kadın kayıplara karıştığında, Zuhal onun ölü bedenini bulur, elini avcuna alır ve yüzünü onun tülbentiyle kaplar. Sonra keçi yeniden görünür ve ortadan yok olur. İşte bu imgeler yığını, dedektif güdülerimizi harekete geçirir; biz de uygar toplumda uyduğumuz baba yasasının tamamen yapay ve istismarcı olduğu, doğayla kopan bağımızın ancak ölüler aracılığıyla sürdürüldüğü, ya da asıl babamızın keçi imgesiyle somutlaşan Dionysos, ya da aynı anlama gelmek üzere, doğa olduğu gibi düşüncelerle oyalanırız. Peki, Dionysos figürüyle ortaya konulan düşünce, eninde sonunda insanın ve insan yapımı olan her şeyin değersiz ve köleleştirici olduğunu mu göstermektir? Yoksa bu figürün asıl vurguladığı, bizi kendi doğamızdan başka bir şey olmayan yazgısal yanımızla yüzleştirmek ve bu yazgı uyarınca katlandığımız her türlü zorlukla bizi barıştırmak mıdır?

Nietzsche' nin betimlediği şekliyle "Dionysosça" olan, asıl olarak "yaşama istencinin kendini sonsuza dek olumlaması" amacını güder ve bu nedenle "doğuran kadının çektiği acı" nın sürekli gerekli olduğuna dikkat çeker (2005a: 111). Acı arttıkça, onun etkide bulunduğu kişiyi yıldıramaması; bu kişideki yaşam istencinin daha yeğin olarak hissedilmesini sağlar. Bir bakıma, kişi, uğradığı 1stıraptan dolayı yıkılmayan birinin yazgısına tanıklık ettiğinde, insan varoluşunu yakınıp dövünecek güçsüzlükte değil acıyı olumlayabilecek güçte görür, ki burada insana asıl değerini veren, hatta yaşamı da insan için değerli kılan bu güçtür. Isşte, Nietzsche' nin ifadesiyle "Dionysosça" olan şudur: "En tuhaf ve en sert sorunlar karşısında bile yaşama evet demek; yaşamin en üstün tiplerinin kurban oluşunda, kendi tükenmezliğinden sevinç duyan yaşama istenci " (2005a: 112). Bu bağlamda, metinlerde tanık olduğumuz acılar, bizi yaşamı en ağır koşulları altında deneyimlemeye yöneltir; ama bizi güçten düşürmek ya da üzmek için değil, yaşamın bu haliyle bile değer taşıdığını göstermek için. Tragedyanın Doğuşu'ndaki şu sözler; 1stırap içindeki insan imgesine bürünmüş Dionysos figürünün ${ }^{7}$ amacını açıkça ortaya koyar: “(...) acı çeken kahramanın imgesinde, görünüş dünyasını göstermekle, yücelttiği nedir_ bu görünüş dünyasının "gerçekliği" hiç değildir, çünkü bize özellikle der ki: "Görün! İyice görün! Budur sizin yaşamınız! Budur akrebi varoluş saatinizin!" (Nietzsche, 2005b: 154). Dolayısıyla, Dionysosçu acı çekme deneyimi, bir yandan bizi kendi yazgımızla ve genel olarak varoluşun yazgısallığıyla yüzleştirir öte yandan bu yazgısallığı en katı biçimiyle dahi benimsememiz gerektiğini gösterir.

Öyle ki bu yüzleşme sonucunda yazgıyı olumlamamız, edilgin bir boyun eğişi yansıtmaz, bizi ne olursa olsun doğru bildiğimizden vazgeçmeme yönünde güdüler. Koca Dünya'ya baktığımızda gözardı edilen bu noktanın, bu filmi -en yumuşak ifadeyle- esinlediğini varsayabileceğimiz Badlands'te dikkate alındığını görürüz. Çünkü Badlands' in kahramanı Kit, yazgısının zorunlu sonucunu tüm ağırlığıyla olumlarcasına, bileklerine kelepçeyi kendisi geçirir ve ardından tüm iyimserliğiyle etinden parçaları ${ }^{8}$ çevresine dağıtır.

Koca Dünya filmine dönersek, filmde kullanıldığı şekliyle Dionysos'un, etkin bir olumlamaya zemin hazırlamadığını söyleyebiliriz. Filmin sonunu hatırlarsak, Zuhal

\footnotetext{
${ }^{6}$ Görüleceği üzere, öz babanın yerine istismarcı bir üvey baba konularak ve sevgililer -yapay biçimde- kardeş kılınarak ilk örneğin olay örgüsü biraz değiştirilmiştir; buradaki amacın -iyimser bir tahminle- esinlenmeyi gözden kaçırmak olduğunu varsayabiliriz.

${ }^{7}$ Bilindiği gibi Nietzsche, Oidipus, Prometheus gibi trajik karakterleri Dionysos' un maskeleri olarak değerlendirir (Nietzsche, 2005b).

${ }^{8}$ Kendisine ait birtakım özel eşyayı.
} 
doğada hastalandıktan sonra Ali'nin elinde kalan tek seçenek, onu bir hastanenin Acil Servisi önünde terk etmektir. Ama uygarlık sınırları içine girdiğinde ise kaçak durumuna düşmüştür; dolayısıyla iki karakterin de artık ne kentte ne de doğada -ya da filmin ismiyle dikkat çekilmeye çalışıldığı üzere "koca dünya" da- gidecek yeri yoktur. Dolayısıyla, doğayla bağı kopmuş olan insan artık yersiz yurtsuzdur ve kalakalmıştır. Bu noktadan sonra, insan yazgısına ilişkin herhangi bir olumlamanın gerçekleştiğini söyleyebilir miyiz? Bunun için en acı koşullarla karşılaşmasına karşın kendi yazgısının ağırlığını yüklenebilen ve yaşamı bu haliyle olumlayabilen bir kişi görmemiz gerekmez miydi? Filmde bir olumlama görmüyor olmamız, aslında gerçek anlamıyla Dionysosçu olana, trajik olana ilişkin de somut bir şey bulunmadığını söyleyebilmemize olanak verir.

Ancak Dionysos figürünün buradaki gibi tek boyutlu haliyle almak, yine de onun en sakıncalı kullanımı değildir. Böyle bir kullanımdan bahsetmek için, çağın bazı olgularını örtmek ve estetik hale getirmek için Dionysos'un büyük ölçüde çarpıtıldığı bir örneğe yer verebiliriz. Bu noktada, Kosmos (Reha Erdem, 2009) filmini hatırladı̆̆ımızda, insan biçimi almış bir Dionysos figürü ile karşılaşırız ki; burada artık filmin başkarakteridir. Bu karakter, sürgüne gelmiş gibi bulunduğu kasabada, Allah sevgisini, aşkı öğütler, haklı ve haksızın, insan ve hayvanın bir ve aynı olduğu yönünde vaazlar verir, zor durumdakilere de şifa dağıtır. Ancak sonunda kasabada hüküm süren askerler, onu sürgüne zorlar ve bir bakıma doğanın kültürle bağını koparırlar. Yine önümüzde öyle elverişli bir imgeler yı̆̆ını vardır ki, onları bizden beklenebileceği şekilde yorumlamak, bu alandaki yetkinlik ve derinliğimizi gösterebilmek için sabırsızlanırız.

Bu bağlamda, söz konusu filmi yorumlarken, dönemin koşullarını, yani sürgüne yollanmaya zorlanmış vaazcı bilgenin aslında kime gönderimde bulunduğunu ya da filmin çekim zamanının tam da siyasal İslamcı bir cemaatin yaptığı bir operasyonla denk düştügüünü görmek istemeyiz'. İçinde bulunduğumuz koşulları göz önünde bulundurarak Dionysos üzerine söylev vermeyi yeğleriz. Ancak olgunun gerçekliğine gözlerimizi kapattığımız için, derin sözler ettiğimizi sanarken yalnızca "suyu bulandırırız"; çünkü somut dayanaktan yoksunluk açık bir anlatım için elverişli değildir ${ }^{10}$.

Benzer şekilde, Koca Dünya'da da, sonunda insanı yüzüstü bırakıp giden Dionysos'u görürüz de, yine aynı dönem pek revaçta olan, kuma getirilen çocuk gelinlerle ilgili tartışmay ${ }^{11}$ görmeyiz. Filmde ele alınan çocuğun şahsında uygarlık tarafından istismara uğramış, ancak doğayla da bağı kopmuş olan insanlık durumunun akıbetini görmeyi yeğleyebiliriz; peki çocuğun uğradığı akıbet, kişiyi aynı şekilde "Koruyucu ailenin yanında kalsa daha iyiydi" diye düşünmeye de sevketmeyecek midir ${ }^{12}$ ? Bizim kendimizce "derin" bir yorumlama biçimini yeğlememiz, bu konuda tam tersi bir yorumun getirilmesinin önüne geçmez. Burada gördügüümüz şudur ki, gerek yazar-yönetmenlerin gerekse sinema üzerine çalışmalar yapan kişilerin felsefi konuları ele alma biçimi, kendi metinlerinin egemenlerce belirlenen dönemsel

\footnotetext{
${ }^{9}$ Filmin çekim yılını hatırlarsak, Balyoz Operasyonunun hemen ertesine denk geldiğini görebiliriz. Üstelik bu operasyonu aklarcasına, taşra kasabasındaki itici otorite figürleri olarak Atatürk büstü ve askerler kullanılmış, vaizin sürgün edilmesine de yine askerler neden olmuştur. Peki sürgüne yollanmış bu bilge vaiz kim olabilir? Biz yine de yanıtı açık görünen bu soruya takılmayıp -kendi pazar yerimizdekilerin genel eğilimine uyarak- bu vaiz imgesinde Dionysos'u görmeye devam edebiliriz.

10 Bu noktada Nietzsche'nin şu sözünü anmamız yerinde olacaktır: "Derin olduklarını bilenler, duru olmaya çalışırlar. Derin görünmek isteyenler, bulanıklık için uğraşırlar. Çünkü kalabalık, dibini görmediği şeyin derin olması gerektiğini düşünür" (2003: 146).

${ }^{11}$ Örneğin, yakın zamanda anımsayacağımız; "Küçüğün rızasıyla olan şeyler bunlar" sözü, tam da filmin çekildiği döneme rastlar.

${ }^{12} \mathrm{Bu}$ konuda filmde açık bir tutum takınılmamasının ardında, belki "dönemin hassasiyetleri" nin iki yanını da düşünme eğilimi yer almış olabilir. Bu noktada bazı filmleri yorumlarken, o filmlerin çekilmesine olanak veren fonların araştırılmasının gerekliliği de ortaya çıkıyor; ancak böyle bir çalışma elbette daha uzun erimli bir çabanın ürünü olacaktır.
} 
duyarlılıklarla, çă̆ın gerekleriyle uygunluğunu örtbas etmek için kullanılabilmektedir.

Öyleyse, çalışmamızın sonuna yaklaşırken, yinelememiz gerekir ki, bir metni okurken birincil amacımız onu gerçekten anlamaktan ziyade kendiçıkarımız uyarınca kullanmak olduğu sürece, başka türden metinleri okurken de yönlendirilmeye açık hale geliriz. Okuduğumuz, izlediğimiz metnin, olgusal yaşamla bağını görmezden gelmek de, yönlendirilmemizi kolaylaştırır. Ancak belki bu durumun pek çoğumuz için önem taşıması da gerekmez. Ne de olsa, bizden bekleneni vermek, hakiki olanı açığa çıkarmaktan daha rahattır; hele bir de derin düşünür olma iddiamızı pekiştiriyorsa.

\section{Sonuç}

Her türlü eylemimize olduğu gibi okuma eylemimize de asıl değerini veren, başkalarının yargılarının yönlendiriciliğgi olmaksızın, onun bizim istencimize uygun biçimde gerçekleşmesidir ki, bunun ardındaki etken de eylemimizin ardındaki dürüst tutumumuzdur. Bir metni okurken takındığımız tutumun dürüstlüğü sonucunda, metni gerek doğrudan karşımızda bulunan olgusallıkla gerekse bu olgusallığ benliğimizle ilişkiye sokar; o metne bir nevi kendi kişiliğimizi yansıtırız. Ancak bu şekilde ulaştı̆̆ımız yorumumuzda ışımakta olan düşünce artık yalnızca bize ait bir gerçekliği dile getirmez; doğrudan olgusal olana, gerçekliğe gönderimde bulunur ve genelleştirilebilecek bir yan taşımaya başlar. Dolayısıyla felsefi metinleri okurken de, bu metinlerin kaynağında, doğrudan yaşamın yer aldığını, yaşamda karşılaşılan temel bir sorunun bulunduğunu gözardı etmememiz gerekir. Yaşamla bağını kurabildiğimiz ölçüde, bu metinleri yerinde bir şekilde değerlendirme yoluna girmişiz demektir.

Bu bağlamda, inceleme konumuz uyarınca serimlemeye çalıştığımız sakıncalı bir noktaya dikkat çekmemiz gerekir. Felsefi metinlerin sinema alanındaki kullanımında pek çok kez karşılaşırız ki, bu metinler bazı durumlarda olguda görünür olanı çarpıtmak için kullanılır, kimi durumlarda ise tek bir boyutuyla ele alınır ve tanınmayacak hale getirilir. Bizler ise, filmlerde bu metinlerin izini sürmeye çalışırken, önümüze konulmuş bazı ipuçlarının peşinde sürüklenip olguda gördüklerimizle, hatta doğrudan yaşamın kendisiyle bağımızı tümden koparabiliriz. Görüleceği üzere, böyle bir durumda ikili bir oyun söz konusudur: bir yanda kendi filmlerinden felsefi çıkarımlar yapılması beklenen kişiler, bu beklentiyi karşılamak adına felsefi metinleri eğip bükenler; diğer yanda ise kendilerine sunulmuş görsel malzemede buldukları düşünce kırıntılarından derin çıkarımlar yapmaya çalışanlar bulunur. Her iki taraf da kendinden bekleneni gerçekleştirirken olguya dayanma zorunluluğunu pek hissetmez; hatta felsefenin kendisine olguda olanı tümüyle görünmez kılma işlevi atfeder.

Çalışmamızda, ülkemiz sinemasından Zeki Demirkubuz ve Reha Erdem'in bazı filmlerinden örnekler verilerek, gerek yönetmenlerin gerekse sinema üzerine çalışmalar yapanların felsefeyi kullanırken çarpıtabilme eğilimlerine dikkat çekilmiştir. Örneğin, filmler yazılır ve değerlendirilirken, Varoluşçu düşünce ile ilişki içine sokulduğunda, bu düşüncenin genel olarak eylemsizlik ve kayıtsızlığa indirgendiğini; ama özsel yanlarına, örneğin eylem ve karakter birliğine, özgürlük ve zorunluluk arasındaki etkileşime pek bir gönderimde bulunulmadığını gözlemleriz. Benzer şekilde, Nietzsche ve Dostoyevski gibi filozof ve yazarların düşüncelerinde, insan salt kötücül ve hayvansı nitelikleriyle bulgulanıyor gibi gösterilir; ancak her iki düşünürün de aşağılık olanda aynı zamanda yüceliğin barındığına yönelik vurguları görmezden gelinir. Benzer şekilde uygarlığa ait her türlü belirlenimi, insanın -usdışı eylemlerine bile kaynaklık eden- ussal yanını aşağıladığımızda, yine bir çıkmaza sürükleniriz. Çünkü insana ilişkin derin çıkarımlar yapma düşüncesiyle onu aşağılayıp içinde bulunduğu çıkmazı vurguladığımızda bu çıkışsızlığın kaynağında, genellikle insanın kendi kötücüllüğünü ve usdış1lı̆̆ını görme yoluna gideriz. Böyle bir durumda ise, kendimizce derin bir irdeleme gerçekleştirirken, aslında egemenlerin çıkarlarını kollarız. Çünkü unutmamamız 
gerekir ki, insandan sahip olduğu şeyleri, uygarlığa ait belirlenimleri çekip aldığınızda geriye kötücül ve aşağılık bir varlık kalır demekle insandaki kötücül eğilimlere içinde bulunduğu koşullar zemin hazırlar demek arasında büyük bir fark vardır. İlk durumda, insanın uğradığı haksızlığı müstahak görme eğilimine girebilecekken, ikincisinde haksızlığın giderilmesi için bir gerekçenin ortaya konulmuş olduğunu görürüz.

Çalışmamızın sonunda söylememiz gerekir ki, bir filmin felsefi bir düşünceyi hakkıyla yansıtma gibi bir misyonu yoktur; tıpkı bir film üzerine yapılan değerlendirmenin de onu felsefi konularla ilişkilendirme misyonu olmaması gibi. Öyleyse, bu noktada, başlangıçta söylediklerimize dönüp yine bir metnin yazımı ve okunmasındaki dürüstlüğün önemini vurgulamamız kaçınılmaz olacaktır. Ancak dürüstçe ortaya konulmuş bir dert, kişiye özgü olsa dahi genelleştirilebilecek bir yan taşır ve biz de ancak bir metni dürüstçe okuyabildiğimizde onun derdini layıkıyla ortaya koyabiliriz. Her iki çabanın da değeri büyüktür ve hem olguların gerçekliğiyle örtüşür hem de derinliği berrak sulara özgü olur.

\section{Kaynakça}

Camus, Albert (2013), Yabancı, (Samih Tiryakioğlu, çev.), İstanbul, Can Yayınları. Yayınları.

Dostoyevski, Fyodor (2003), Karamazov Kardeşler, (Ergin Altay, çev.), İstanbul, İletişim

Dostoyevski, Fyodor (2007), Suç ve Ceza, (Ergin Altay, çev.), İstanbul, İletişim Yayınları.

Dostoyevski, Fyodor (2010), Yeraltından Notlar, (Mehmet Özgül, çev.), İstanbul, İletişim Yayınları.

Hegel, W. Friedrich (1969), Science of Logic, (A. Miller, çev.), New York, Humanity Books. Yayınevi.

Hegel, W. Friedrich (2004), Tinin Görüngübilimi, (Aziz Yardımlı, çev.), İstanbul, İdea

Hegel, W. Friedrich (2014), Tarihte Akıl, (Önay Sözer, çev.), İstanbul, Kabalcı Yayınları.

Nietzsche, Friedrich (1998), Ahlakdışı Anlamda Doğruluk ve Yalan Üzerine, (Oruç Arıoba, çev.) Cogito:16 Yalan içinde, İstanbul, Yapı Kredi Yayınları.

Nietzsche, Friedrich (2000), Böyle Buyurdu Zerdüşt, (Turan Oflazoğlu, çev.), İstanbul, Cem Yayınevi.

Nietzsche, Friedrich (2003), Şen Bilim, (Levent Özşar, çev.), Bursa, Asa Kitabevi. Yayınları.

Nietzsche, Friedrich (2005a), Putların Batışı, (Mustafa Tüzel, çev.), İstanbul, İthaki

Nietzsche, Friedrich (2005b), Tragedyanın Doğuşu, (Mustafa Tüzel, çev.), İstanbul, İthaki Yayınları.

Nietzsche, Friedrich (2016), İyinin ve Kötünün Ötesinde, (Mustafa Tüzel, çev.), İstanbul, Türkiye İş Bankası Kültür Yayınları.

Sartre, Jean Paul (2009), Varlık ve Hiçlik, (Turhan Ilgaz, Gaye Çankaya Eksen, çev.), İstanbul, İthaki Yayınları.

Sartre, Jean Paul (2010), Bulantı, (Selahattin Hilav, çev.), İstanbul, Can Yayınları. 
Sartre, Jean Paul (2011), Akıl Çağı, (Gülseren Devrim, çev.), İstanbul, Can Yayınları.

Schelling, F.W.J. von (2017), İnsan Özgürlüğ̈̈nün Özü Üzerine, (Mehmet Barış Albayrak, çev.), İstanbul, Ayrıntı Yayınları.

\section{Metinde Adı Geçen Filmler}

Demirkubuz, Z. (Yapımcı) \& Demirkubuz, Z. (Yönetmen). (2001). Yazgı [Sinema Filmi]. Türkiye: Mavi Film.

Demirkubuz, Z. (Yapımc1) \& Demirkubuz, Z. (Yönetmen). (2010). Yeraltı [Sinema Filmi]. Türkiye: Tiglon.

Emre, B., Boyacıoğlu, A. (Yapımc1) \& Demirkubuz, Z. (Yönetmen). (2015). Bulantı [Sinema Filmi]. Türkiye: Mavi Film.

Atay. Ö (Yapımc1) \& Erdem, R. (Yönetmen). (2009). Kosmos [Sinema Filmi]. Türkiye: Atlantik Film, İmaj.

Atay. Ö (Yapımc1) \& Erdem, R. (Yönetmen). (2016). Koca Dünya. [Sinema Filmi]. Türkiye: Atlantik Film, Maya Film.

Malick, T. (Yapımc1) \& Malick, T. (Yönetmen). (1973). Badlands [Sinema Filmi]. U.S.A.: Warner Bros. 